\title{
Mass Spectral Analysis of the Aged 1,3,5-Trimethylbenzene Secondary Organic Aerosol in the Presence of Ammonium Sulfate Seeds
}

\author{
Mingqiang Huang ${ }^{1,2 *}$, Jun $\mathrm{Xu}^{1}$, Shunyou Cai ${ }^{1}$, Xingqiang Liu ${ }^{2}$, \\ Changjin $\mathrm{Hu}^{3}$, Xuejun $\mathrm{Gu}^{3}$, Li Fang ${ }^{3}$, Weijun Zhang*** \\ ${ }^{1}$ Fujian Provincial Key Laboratory of Modern Analytical Science and Separation Technology, \\ College of Chemistry and Environment, Minnan Normal University, \\ Zhangzhou 363000, China \\ ${ }^{2}$ Department of Environmental Science and Engineering, Xiamen University, \\ Tan Kah Kee College, 363105 Zhangzhou, China \\ ${ }^{3}$ Laboratory of Atmospheric Physico-Chemistry, Anhui Institute of Optics and Fine Mechanics, \\ Chinese Academy of Sciences, Hefei 230031, China
}

Received: 12 September 2016

Accepted: 6 November 2016

\begin{abstract}
The ammonium sulfate $\left(\left(\mathrm{NH}_{4}\right)_{2} \mathrm{SO}_{4}\right)$ seed aerosols commonly found in the Chinese urban atmosphere could affect the formation and aging of secondary organic aerosols (SOA). Aging of aromatic SOA is performed using UV-irradiation of 1,3,5-trimethylbenzene (135-TMB)/ $\mathrm{CH}_{3} \mathrm{ONO} / \mathrm{NO} /$ air mixtures with high concentrations $\left(\sim 100 \mu \mathrm{g} / \mathrm{m}^{3}\right)$ of $\left(\mathrm{NH}_{4}\right)_{2} \mathrm{SO}_{4}$ seeds in the laboratory chamber in this study. The particulate products of SOA were measured using an aerosol laser time-of-flight mass spectrometer (ALTOFMS) in real-time, and fuzzy c-means (FCM) was applied to the mass spectra organic species for clusters. Experimental results indicated that methylglyxoal, 2-methyl-4-oxo-2-pentenal, 4-methyl-1H-imidazole, 4-methyl-imidazole-2-acetaldehyde, and other imidazole derivative compounds are the principal products in the aged particles. Imidazole compounds that can absorb solar radiation effectively were newly detected in the aged 135-TMB SOA with high concentrations of $\left(\mathrm{NH}_{4}\right)_{2} \mathrm{SO}_{4}$ seed aerosols. These would provide new information for discussing the 135-TMB SOA aging mechanism.
\end{abstract}

Keywords: 1,3,5-trimethylbenzene, ammonium sulfate, secondary organic aerosol, laser time-of-flight mass spectrometer, aging mechanisms

*e-mail: huangmingqiang@gmail.com

**e-mail: wjzhang@aiofm.ac.cn 


\section{Introduction}

Plants are important natural resources for human beings. They can reduce carbon dioxide in the atmosphere via photosynthesis [1-3]. The growth of plants is affected by serious environmental pollution. The effects of water stress [4], drought stress [5], and some hormone applications [67] on germination and morphological characteristics of endangered plant species have been carried out by some researchers. Also, genetic improvement has been used to increase the variety and availability of plants [8]. However, plants can also emit isoprene, pinene, and other volatile organic compounds that are responsible for biogenic secondary organic aerosol (SOA) through photochemical reaction in the atmosphere [9]. Compared to biogenic SOA, anthropogenic SOA is formed from photooxidation of 1,3,5-trimethylbenzene (135-TMB) and other aromatic hydrocarbons emitted from human activities, such as motor vehicle exhaust and evaporation of solvents [10].

SOA can undergo continuous physical and chemical processing, commonly called aging $[11,12]$. The chemical composition, volatility, and other properties change as SOA ages [13-14]. SOA aging has attracted great attention because of the impact of aged SOA on the visibility of air [15], the formation of clouds, climate change [16], and human health [17]. In recent years, aromatic SOA aging studies have focused on identifying the aged products [18-20]. Chemical composition of the aged SOA particles was often studied by using offline techniques. The aged particles were usually collected using filters or an impactor plate and samples were prepared by way of chemical extracts. Molecular composition of aging SOA particles could be analyzed by a gas chromatograph-mass spectrometer (GC-MS) or liquid chromatograph-mass spectrometer (LC-MS). Sato et al. [20] have measured the chemical structure of the aged benzene and 135-TMB SOA with LC-MS, and dialdehydes, caroboxylic acids, ketoaldehydes, ketocarboxylic acids, and oxo-carboxylic acids were detected. However, the offline measurements are time-consuming with low sampling resolution and tend to lead to sampling artifacts [21].

An aerosol laser time-of-flight mass spectrometer (ALTOFMS) is notable for its capability to simultaneously determine both the size and chemical composition of individual particles in real-time [22]. Unlike conventional aerosol instruments, during the ALTOFMS continuous operation, thousands of mass spectra are obtained per experiment. Manual analysis of mass spectra is not an efficient procedure. Therefore, various statistical methods have been applied to classify the mass spectra of individual particles according to their chemical composition [23]. One of the most useful methods is the fuzzy c-means (FCM) algorithm [24], which is an efficient way of intelligently finding clusters in data sets with large numbers of variables. Recently, FCM has been exploited to classify the mass spectra of particles achieved by ALTOFMS [25]. This technique has been successfully applied to study the aged 135-TMB SOA, allowing for a clear identification of 12 classes, indicating that ALTOFMS coupled with the
FCM can successfully conduct cluster analysis of SOA [26].

It is known that aromatic SOA formation and aging are related to preexisting particles [27]. Ammonium sulfate $\left(\left(\mathrm{NH}_{4}\right)_{2} \mathrm{SO}_{4}\right)$, which is formed by the reaction of $\mathrm{NH}_{3}$ with $\mathrm{H}_{2} \mathrm{SO}_{4}$, is one of the most common inorganic seed aerosols in an urban atmosphere [28]. Previous $\left(\mathrm{NH}_{4}\right)_{2} \mathrm{SO}_{4}$ seed studies emphasize the effect on SOA mass yields in the smog chamber. Wyche et al. [29] found that $\left(\mathrm{NH}_{4}\right)_{2} \mathrm{SO}_{4}$ seeds with low concentrations $\left(0.2 \sim 40 \mu \mathrm{g} \mathrm{m}^{-3}\right)$ had no detectable influence on mass yields of aromatic SOA. By contrast, mass yields of m-xylene SOA were clearly raised with high concentrations $\left(40 \sim 100 \mu \mathrm{g} \mathrm{m}^{-3}\right)$ of $\left(\mathrm{NH}_{4}\right)_{2} \mathrm{SO}_{4}$ seeds [30]. However, the detailed chemical compositions of aromatic SOA were not considered in these studies. Also, previous aromatic SOA aging experiments were carried out with or without low inorganic seeds. The influence of high seeds on the aged aromatic SOA composition has not been investigated at present. So, the chemical compositions of the aged 135-TMB SOA with high concentrations $\left(\sim 100 \mu \mathrm{g} \mathrm{m}^{-3}\right)$ of $\left(\mathrm{NH}_{4}\right)_{2} \mathrm{SO}_{4}$ seed aerosols were measured online using ALTOFMS coupled with FCM, and the reaction mechanisms of the aged products were also reported.

\section{Material and Methods}

\section{Aerosol Laser Time-Of-Flight Mass Spectrometer (ALTOFMS)}

A home-built ALTOFMS $[25,26]$ was used to analyze the size and chemical composition of the aged 135-TMB SOA particles. As shown in Fig. 1, ALTOFMS is composed of an inlet system with aerodynamic lens, a sizing system for particle detection and velocity/size determination, a chemical component analyzing system, and an FCM data processing system. Similar to commercial aerosol timeof-flight mass spectrometers (TSI 3800-100), the transmit particles of ALTOFMS is in the range of from 200 to

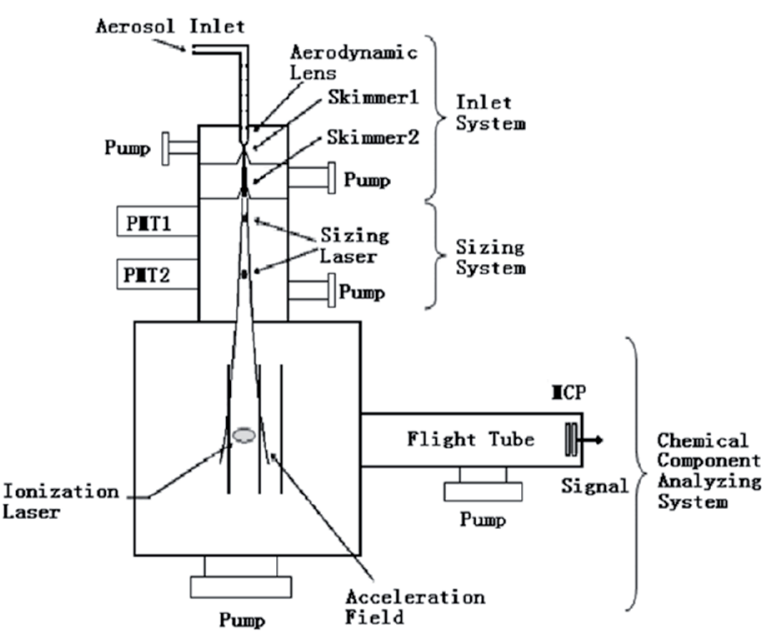

Fig. 1. Schematic diagram of the aerosol laser time-of-flight mass spectrometer (ALTOFMS). 

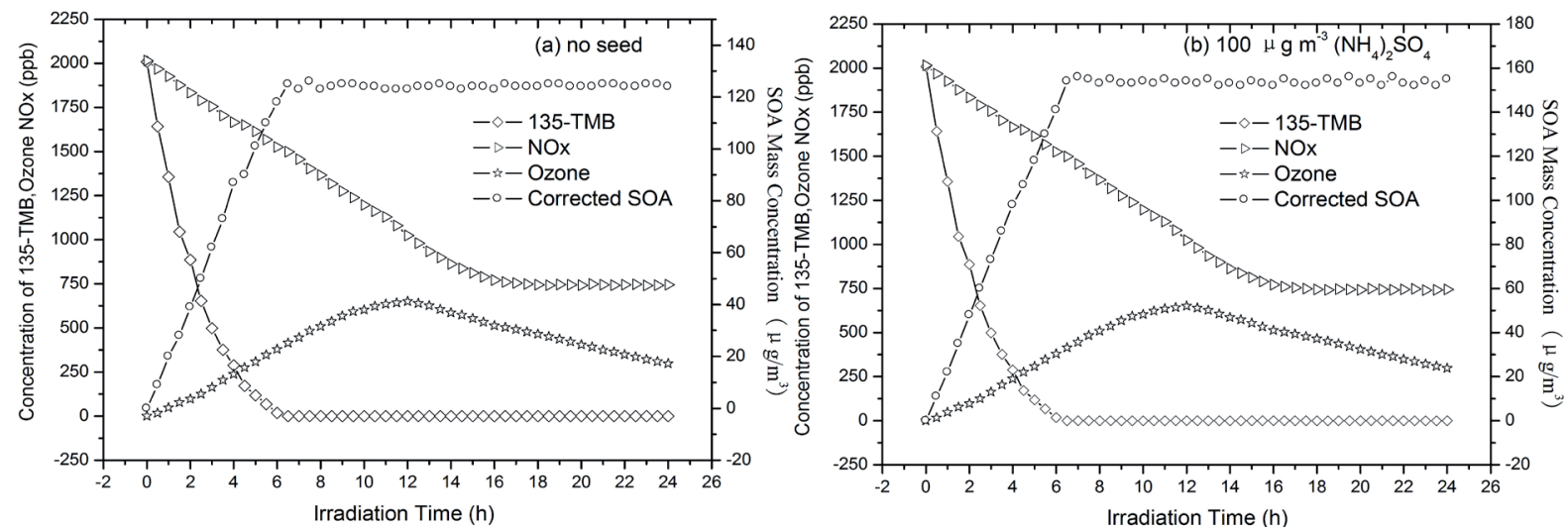

Fig. 2. The 135-TMB, $\mathrm{NO}_{x}, \mathrm{O}_{3}$, and corrected SOA concentrations at different times with a) no seed and b) $100 \mu \mathrm{g} \mathrm{m}^{-3}\left(\mathrm{NH}_{4}\right)_{2} \mathrm{SO}_{4}$ seeds.

3,000 $\mathrm{nm}$, and mass range of $1-800 \mathrm{amu}$ with full width at half maximum (FWHM) of 500. In the FCM data processing system, the particle mass spectra were calibrated using software that was compiled in Visual C++. Each revised spectrum is then converted to a normalized 300-point vector, with each point representing one mass unit. The data vectors of all particles measured are written into a classification matrix. Each spectrum's data was stored as one row in this matrix. Then the individual particles were clustered using the FCM as described in detail in our previous studies $[25,26]$.

\section{5-TMB SOA Aging in the Presence of $\left(\mathrm{NH}_{4}\right)_{2} \mathrm{SO}_{4}$ Seed Aerosols}

$\left(\mathrm{NH}_{4}\right)_{2} \mathrm{SO}_{4}$ seeds were produced by aspirating $0.001 \mathrm{~mol} / \mathrm{L}$ of salt solution through a constant output atomizer (TSI Inc. Model 3076, USA), and subsequently passed through a diffusion dryer (TSI Inc. Model 3062, USA) and an ${ }^{85} \mathrm{Kr}$ charge neutralizer (TSI Inc., Model 3054, USA) before entering the chamber [25]. The average diameter and concentration of the $\left(\mathrm{NH}_{4}\right)_{2} \mathrm{SO}_{4}$ seeds in chamber was about $100 \mathrm{~nm}$ and $100 \mu \mathrm{g} / \mathrm{m}^{3}$, respectively.

Aging of 135-TMB SOA is performed using UVirradiation of $135-\mathrm{TMB} / \mathrm{CH}_{3} \mathrm{ONO} / \mathrm{NO} /$ air mixtures in the absence and presence of $\sim 100 \mu \mathrm{g} \mathrm{m}^{-3}$ of $\left(\mathrm{NH}_{4}\right)_{2} \mathrm{SO}_{4}$ seeds in an $850 \mathrm{~L}$ smog chamber $[25,26]$. After flushing the smog chamber and obtaining the desired $\left(\mathrm{NH}_{4}\right)_{2} \mathrm{SO}_{4}$ seeds, 135-TMB, $\mathrm{NO}$, and $\mathrm{CH}_{3} \mathrm{ONO}$ were introduced into the smog chamber, and then the chamber was filled with the purified air to full volume. The concentrations of $135-\mathrm{TMB}, \mathrm{CH}_{3} \mathrm{ONO}$, and $\mathrm{NO}$ are $2.0 \mathrm{ppm}, 20.0 \mathrm{ppm}$, and $2.0 \mathrm{ppm}$, respectively. GC-FID (Agilent 7820A, USA), an $\mathrm{NO}-\mathrm{NO}_{2}-\mathrm{NO}_{x}$ analyzer (TEI model 42i), an $\mathrm{O}_{3}$ analyzer (TEI model 49i), and scanning mobility particle sizer (TSI 3080L DMA, TSI 3775 CPC) were used to measure the concentrations of 135-TMB, $\mathrm{NO}_{x}, \mathrm{O}_{3}$, and the volume concentration and mobility size distributions of SOA particles, respectively. To achieve longer $\mathrm{OH}$ exposure times, measurements with all instruments were made every $30 \mathrm{~min}$.

The average concentration of $\mathrm{OH}$ radicals formed from UV-irradiation of $\mathrm{CH}_{3} \mathrm{ONO}$ [31] got to maximum immediately after turning on four black lamps and then decreased with time for each experiment. However, the average concentration of $\mathrm{OH}$ radicals in chamber kept $>1 \times 10^{7}$ molecules $\mathrm{cm}^{-3}$ during photooxidation, indicating that the particles and vapors were continuously oxidized during irradiation [26]. After 24 hours of photooxidation, the aged 135-TMB SOA particles were continuously analyzed using the ALTOFMS in real-time and the produced mass spectra of the aged particles were clustered by FCM $[25,26]$.

\section{Results and Discussion}

The time series of the 135-TMB, $\mathrm{NO}_{x}, \mathrm{O}_{3}$, and SOA concentrations that were corrected for wall loss [32] are displayed in Fig. 2. The changes of $\mathrm{NO}_{x}, 135-\mathrm{TMB}$, and $\mathrm{O}_{3}$ concentrations are nearly the same in these two experiments, indicating that the presence of high seeds has no obvious influence on $\mathrm{O}_{3}$ formation, showing a very good agreement with the findings reported by $\mathrm{Lu}$ et al. [30]. The corrected maximum SOA mass concentration with $\left(\mathrm{NH}_{4}\right)_{2} \mathrm{SO}_{4}$ seeds is $150 \mu \mathrm{g} \mathrm{m}^{-3}$, higher than that in the unseeded experiment and showing that high

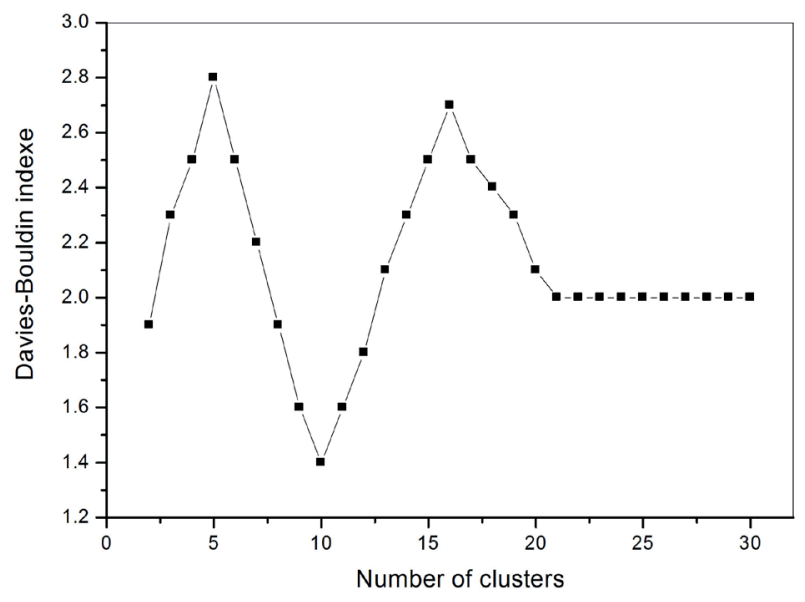

Fig. 3. The clustering number of the Davies-Bouldin index for the aged 135-TMB SOA particles with $\left(\mathrm{NH}_{4}\right)_{2} \mathrm{SO}_{4}$ seeds. 

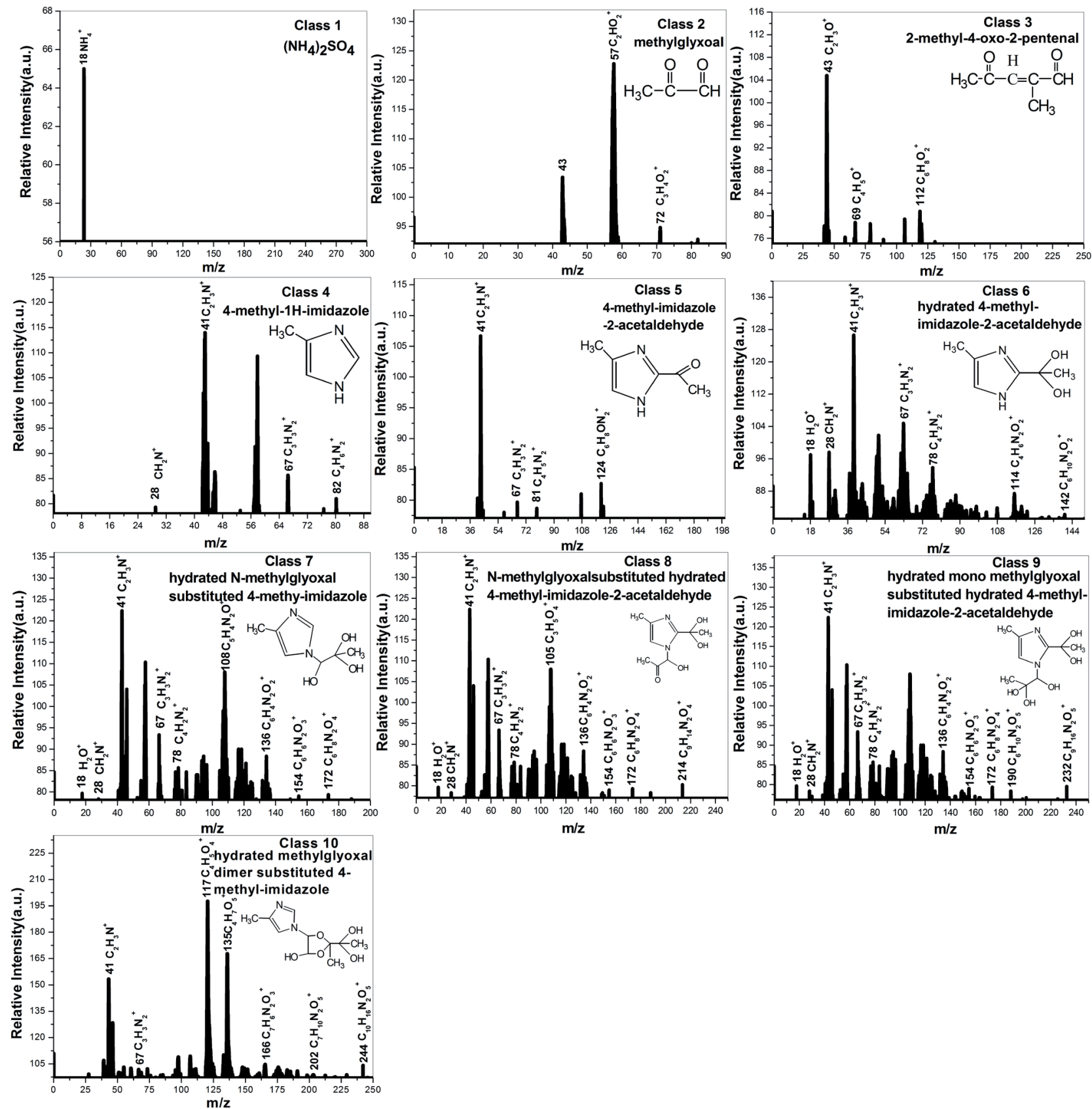

Fig. 4. Spectra patterns of the aged 135-TMB SOA particles with $\left(\mathrm{NH}_{4}\right)_{2} \mathrm{SO}_{4}$ seeds as determined by FCM.

concentrations of $\left(\mathrm{NH}_{4}\right)_{2} \mathrm{SO}_{4}$ seeds enhance SOA formation. It also can be seen from Fig. 2 that the SOA mass concentration reached the maximum at about 6 hours, and afterward SOA aging occurred for another 18 hours. After 24-hour photooxidation, the SOA particles in the smog chamber are the aged SOA particles. The constituents of the aged 135-TMB SOA with $\left(\mathrm{NH}_{4}\right)_{2} \mathrm{SO}_{4}$ seeds are discussed in the following sections.

\section{The Aged Products of 135-TMB SOA with $\left(\mathrm{NH}_{4}\right)_{2} \mathrm{SO}_{4}$ Seeds}

After setting the FCM initial parameters as mentioned in our previous studies [25-26], 6,564 pieces of mass spectra of the aged 135-TMB SOA particles with $\left(\mathrm{NH}_{4}\right)_{2} \mathrm{SO}_{4}$ seeds were processed to extract out clusters. As shown in Fig. 3, the Davies-Bouldin index has the minimum at $\mathrm{n}=10$, indicating that these mass spectra of the aged particles can be clustered into 10 classes. The mass spectra of these 10 clusters are different from those observed in our previously aged 135-TMB SOA study without seed aerosol [26], indicating that new particulate products were formed. The first class I has the only peak of $\mathrm{m} / \mathrm{z} 18$, which is representative of ammonium ion $\left(\mathrm{NH}_{4}^{+}\right)$ $[32,33]$. The patterns of classes II and III resemble the mass spectra of methylglyxoal and 2-methyl-4-oxo-2-pentenal, which were detected in our previous photooxidation experiment of 135-TMB [26]. Thus, these two compounds 


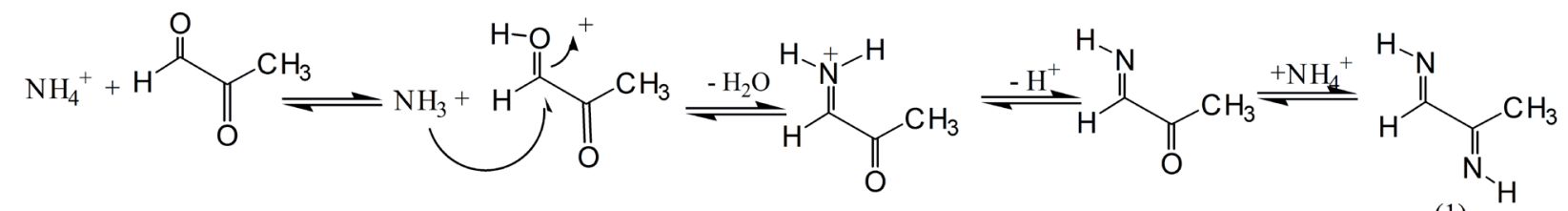

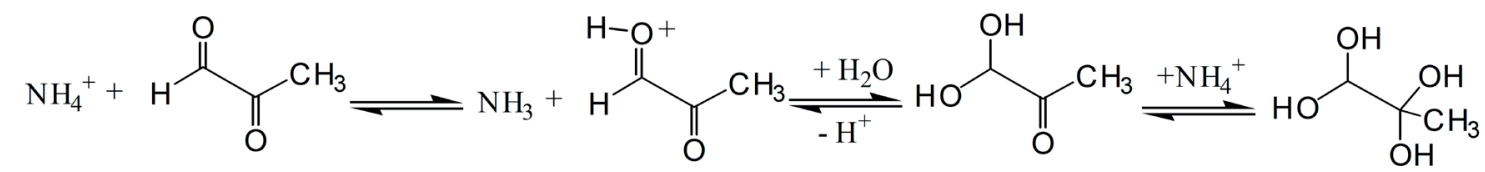

(1)

(2)

(3)

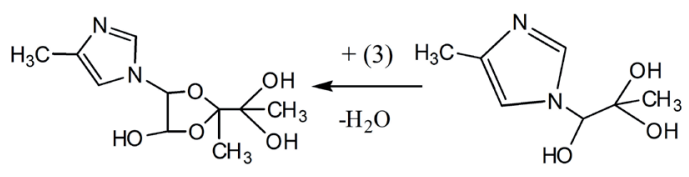

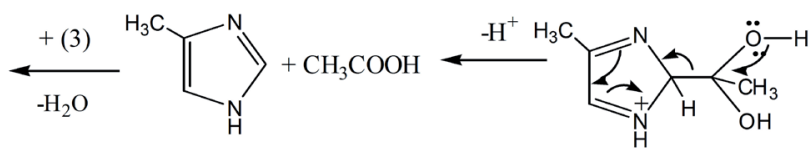

(8)

(7)

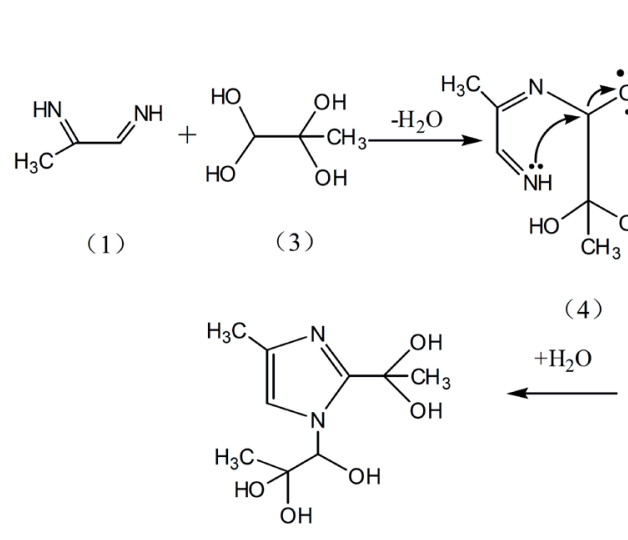

(12)
(4)<smiles>CC(=O)C(O)n1cc(C)nc1C(C)(O)O</smiles>

(11)
(6)
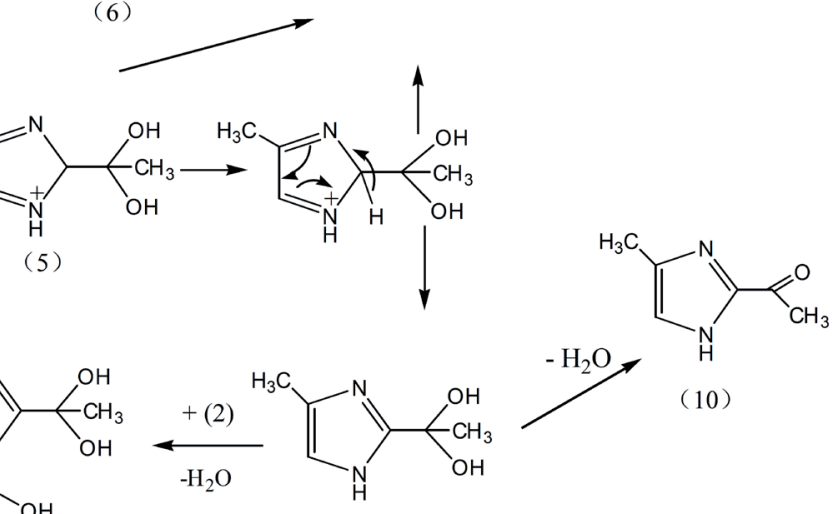

(9)

Fig. 5. The proposed reaction mechanisms of imidazole product generation via ammonium ion reactions with methylglyoxal.

were identified accordingly. Classes IV to $\mathrm{X}$ have specific fragment peaks at $\mathrm{m} / \mathrm{z} 41\left(\mathrm{C}_{2} \mathrm{H}_{3} \mathrm{~N}^{+}\right)$and $\mathrm{m} / \mathrm{z} 67\left(\mathrm{C}_{3} \mathrm{H}_{3} \mathrm{~N}_{2}^{+}\right)$, and we tentatively identified these clusters to be imidazole compounds [34-36]. The speculated molecular structures of these imidazole products are exhibited in Fig. 4. These seven chemical clusters are different from the major components in a similar 135-TMB SOA aging study conducted previously but without seeds, where aromatic organic acid, organic nitrogen-containing products, oxocarboxylic acid, and high-molecular-weight (HMW) compounds were measured [26].

\section{The Reaction Mechanisms of the Aged Products}

The clustering results show that $\left(\mathrm{NH}_{4}\right)_{2} \mathrm{SO}_{4}$ seeds can promote the formation of imidazole compounds in the aged 135-TMB SOA. As proposed by Meyer et al. [37], $\left(\mathrm{NH}_{4}\right)_{2} \mathrm{SO}_{4}$ seeds can produce $\mathrm{NH}_{4}^{+}$ion by absorbing water vapor, and the reaction of $\mathrm{NH}_{4}^{+}$with methylglyoxal produces imidazole products [34-36]. The generated gas-phase methylglyoxal can condense on existing $\left(\mathrm{NH}_{4}\right)_{2} \mathrm{SO}_{4}$ seeds. As shown in Fig. 5, similar to glyoxal, methylglyoxal is protonated by the $\mathrm{NH}_{4}^{+}$and a subsequent attack by $\mathrm{NH}_{3}$ to form diimine (1). Also, the protonated methylglyoxal can hydrolysis to generate diol (2) and tetrol products (3). (1) can react with (3) to produce intermediate compound (4) after dehydration. (4) is unstable due to $\mathrm{N}$ atom attack to the $\mathrm{C}$ atom leads to the formation of compound (5), which generates $\mathrm{HCOOH}$ and 4-methyl-1H-imidazole (6) via electronic rearrangement and fracture dehydration reaction. (6) can continue to react with (3) to form hydrated N-methylglyoxal substituted 4-methyl-imidazole (7), and hydrated methylglyoxal dimer substituted 4-methyl-imidazole (8) after dehydration, respectively. In addition, electron rearrangement can occur in compound (5) as shown in Fig. 5 to form the hydrated 4-methyl-imidazole-2-acetaldehyde (9). (9) can be dehydrated to generate 4-methyl-imidazole2-acetaldehyde (10), or continue to react with (2) to form N-methylglyoxal substituted hydrated 4-methylimidazole-2-acetaldehyde (11) after dehydration, (11) further hydration to produce mono methyl glyoxal substituted hydrated 4-methyl-imidazole-2-acetaldehyde (12) [34-36].

\section{Comparison with Previous Inorganic Seeds Studies}

$\mathrm{Lu}$ et al. [30] recently found that m-xylene SOA yield was enhanced with high concentrations of $\left(\mathrm{NH}_{4}\right)_{2} \mathrm{SO}_{4}$ seeds. They suggested that the thickness of the organic 
layer plays an important role in SOA formation. With the same amount of SOA generation, the seed surface concentration is approximately inversely proportional to the thickness of the organic layer. The thinner the organic layer, the more pronounced the SOA formation enhancement from the $\left(\mathrm{NH}_{4}\right)_{2} \mathrm{SO}_{4}$ seeds. Compared to the published inorganic seeds smog chamber experiments, our work characterized the aged 135-TMB SOA by high concentrations of $\left(\mathrm{NH}_{4}\right)_{2} \mathrm{SO}_{4}$ seeds in real-time. The detailed chemical composition of the aged 135TMB SOA obtained by ALTOFMS coupled with FCM suggested that imidazole compounds are newly detected as the major aging products in the aged particles with high concentrations of $\left(\mathrm{NH}_{4}\right)_{2} \mathrm{SO}_{4}$ seeds. Based on the hypothesis of $\mathrm{Lu}$ et al. [30], the effects of the high concentration of $\left(\mathrm{NH}_{4}\right)_{2} \mathrm{SO}_{4}$ seeds on the chemical constituent of the aged 135-TMB SOA can be explicated. With the same amount of 135-TMB SOA generation, higher $\left(\mathrm{NH}_{4}\right)_{2} \mathrm{SO}_{4}$ seed aerosol concentration enables a thinner organic layer. Also, high $\left(\mathrm{NH}_{4}\right)_{2} \mathrm{SO}_{4}$ seed aerosol concentration provides more reactive sites for heterogeneous reactions [27, 38]. Thus, high concentrations of $\left(\mathrm{NH}_{4}\right)_{2} \mathrm{SO}_{4}$ seeds induce the heterogeneous reactions, and facilitate the formation of imidazole compounds as mentioned above. These would provide new information for discussing the 135-TMB SOA aging mechanism.

\section{Conclusions}

The SOA formation and aging are related to the inorganic seed aerosols whose surface area can play an important role in the adsorption and catalytic reactions. Our experimental results indicated that imidazole products are the main components in the aged 135-TMB SOA with $\sim 100 \mu \mathrm{g} / \mathrm{m}^{3}$ of $\left(\mathrm{NH}_{4}\right)_{2} \mathrm{SO}_{4}$ seeds, which are commonly found in Chinese urban atmosphere. Studies have shown that imidazole compounds can absorb solar radiation efficiently, resulting in the decrease of air visibility [18, 35-36]. The optical parameters of aged aromatic SOA should be considered in further investigations.

\section{Acknowledgements}

This work was supported by the National Natural Science Foundation of China (Nos. 41575118, 41305109, 21502086, and 41575126), the Outstanding Youth Science Foundation of Fujian Province of China (No. 2015J06009), and the Natural Science Foundation of Fujian Province of China (No. 2015J05028). Also, the authors express their gratitude to the referees for their valuable comments.

\section{References}

1. CETIN M., SEVIK H. Measuring the impact of selected plants on indoor $\mathrm{CO}_{2}$ concentrations. Pol. J. Environ. Stud. 25 (3), 973, 2016.
2. CETIN M. A change in the amount of $\mathrm{CO}_{2}$ at the center of the examination halls: case study of Turkey. Ethno. Med. 10 (2), 146, 2016.

3. SEVIK H., CETIN M., BELKAYALI N. Effects of forests on amounts of $\mathrm{CO}_{2}$ : case study of Kastamonu and Ilgaz Mountain National Parks. Pol. J. Environ. Stud. 24 (1), 253, 2015.

4. SEVIK H., CETIN M. Effects of water stress on seed germination for select landscape plants. Pol. J. Environ. Stud. 24 (2), 689, 2015.

5. YIGIT N., SEVIK H., CETIN M., KAYA N. Determination of the effect of drought stress on the seed germination in some plant species. Water Stress in Plants, 1st ed.; RAHMAN I.M.M., BEGUM Z.A., HASEGAWA H., InTechOpen Company: Vienna, Austria, Chapter 3, pp. 43, 2016.

6. SEVIK H., CETIN M. Effects of some hormone applications on germination and morphological characters of endangered plant species Lilium artvinense L. Onion scales. Bulg. Chem. Commun. 48 (2), 256, 2016.

7. GUNEY K., CETIN M., SEVIK H., GUNEY K.B. Influence of germination and morphological properties of some hormone practice on Lilium martagon L. Seeds. Oxid. Commun. 39 (1-II), 466, 2016.

8. YIGIT N., SEVIK H., CETIN M., GUL L. Clonal variation in chemical wood characteristics in Hanönü (Kastamonu) Günlüburun black pine (Pinus nigra Arnold. subsp. Pallasiana (Lamb.) Holmboe) seed orchard. J. Sustain. Forest. 35 (7), $515,2016$.

9. TU P.J., HALLIV W.A., JOHNSTON M.V. Characterization of highly oxidized molecules in fresh and aged biogenic secondary organic aerosol. Anal. Chem. 88 (8), 4495, 2016.

10. BOLDEN A.L., KWIATKOWSKI C.F., COLBORN T. New look at BTEX: are ambient levels a problem? Environ. Sci. Technol. 49 (9), 5261, 2015.

11. ANDREAE M.O. A new look at aging aerosols. Science 326 (5959), 1493, 2009.

12. RUDICH Y., DONAHUE N.M., THOMAS F., MENTEL T.F. Aging of organic aerosol: bridging the gap between laboratory and field studies. Annu. Rev. Phys. Chem. 58, 321, 2007.

13. NG N.L., CANAGARATNA M.R., JIMENEZ J.L., CHHABRA P.S., SEINFELD J.H., WORSNOP D.R. Changes in organic aerosol composition with aging inferred from aerosol mass spectra. Atmos. Chem. Phys. 11 (13), 6465, 2011.

14. TRITSCHER T., DOMMEN J., DECARLO P.F., GYSEL M., BARMET P.B., PRAPLAN A.P., WEINGARTNER E., PRéVôT H.A.S., RIIPINEN I., DONAHUE N. M., BALTENSPERGER U. Volatility and hygroscopicity of aging secondary organic aerosol in a smog chamber. Atmos. Chem. Phys. 11 (22), 11477, 2011.

15. BALTENSPERGER U. Aerosols in clearer focus. Science 329 (5998), 1468, 2010.

16. LEE H.J., AIONA P.K., LASKIN A., LASKIN J., NIZKORODOV S.A. Effect of solar radiation on the optical properties and molecular composition of laboratory proxies of atmospheric brown carbon. Environ. Sci. Technol. 48 (17), 10217, 2014.

17. ROHR A., MCDONALD J. Health effects of carboncontaining particulate matter: focus on sources and recent research program results. Crit. Rev. Toxicol. 46 (2), 97, 2016.

18. UPDYKE K.M., NGUYEN T.B., NIZKORODOV S.A. Formation of brown carbon via reactions of ammonia with secondary organic aerosols from biogenic and anthropogenic precursors. Atmos. Environ. 63, 22, 2012. 
19. LOZA C.L., CHHABRA P.S., YEE L.D., CRAVEN J.S., FLAGAN R.C., SEINFELD J.H. Chemical aging of m-xylene secondary organic aerosol: laboratory chamber study. Atmos. Chem. Phys. 12 (1), 151, 2012.

20. SATO K.; TAKAMI A., KATO Y., SETA T., FUJITANI Y., HIKIDA T., SHIMONO A., IMAMURA T. AMS and LC/ MS analyses of SOA from the photooxidation of benzene and 1,3,5-trimethylbenzene in the presence of $\mathrm{NO}_{\mathrm{x}}$ : effects of chemical structure on SOA aging. Atmos. Chem. Phys. 12 (10), 4667, 2012.

21. FISSEHA R., DOMMEN J., SAX M., PAULSEN D., KALBERER M., MAURER R., HÖLFLER F., WEINGARTNER E., BALTENSPERGER U. Identification of organic acids in secondary organic aerosol and the corresponding gas phase from chamber experiments. Anal. Chem. 76 (22), 6535, 2004.

22. PRATT K.A., PRATHER K.A. Mass spectrometry of atmospheric aerosols - recent developments and applications. Part II: on-line mass spectrometry techniques. Mass Spectrom. Rev. 31 (1), 1, 2011.

23. ZHAO W.X., HOPKE P.K., PRATHER K.A. Comparison of two cluster analysis methods using single particle mass spectra. Atmos. Environ. 42 (5), 881, 2008.

24. BEZDEK J.C. Pattern recognition with fuzzy objective function algorithms, 1st ed.; Plenum Press: New York, USA, 43, 1981.

25. HUANG M.Q., HAO, L.Q., GUO X.Y., HU C.J., GU X.J., ZHAO W.X., WANG Z.Y., FANG L., ZHANG W.J. Characterization of secondary organic aerosol particles using aerosol laser time-of-flight mass spectrometer coupled with FCM clustering algorithm. Atmos. Environ. 64, 85, 2013.

26. HUANG M.Q., LIN Y.H., HUANG X.Y., LIU X.Q., GUO X.Y., HU C.J., ZHAO W.X., GU X.J., FANG L., ZHANG W.J. Experimental study of particulate products for aging of 1,3,5-trimethylbenzene secondary organic aerosol. Atmos. Pollut. Res. 6 (2), 209, 2015.

27. JANG M., CZOSCHKE N.M., LEE S., KAMENS R.M. Heterogeneous atmospheric aerosol production by acidcatalyzed particle-phase reactions. Science 298 (5594), 814, 2002.

28. ROBINSON C.B., SCHILL G.P., ZARZANA K.J., TOLBERT M.A. Impact of organic coating on optical growth of ammonium sulfate particles. Environ. Sci. Technol. 47 (23), 13339, 2013.

29. WYCHE K.P., MONKS P.S., ELLIS A.M., CORDELL R.L., PARKER A.E., WHYTE C., METZGER A., DOMMEN J., DUPLISSY J., PREVOT A.S.H., BALTENSPERGER U., RICKARD A.R., WULFERT F. Gas phase precursors to anthropogenic secondary organic aerosol: detailed observations of 1,3,5-trimethylbenzene photooxidation. Atmos. Chem. Phys. 9 (2), 635, 2009.

30. LU Z.F., HAO J.M., TAKEKAWA H., HU L.H., LI J.H. Effect of high concentrations of inorganic seed aerosols on secondary organic aerosol formation in the m-xylene/ $\mathrm{NO}_{x}$ photooxidation system. Atmos. Environ. 43 (4), 897, 2009.

31. ATKINSON R., CARTER W.P.L., WINER A.M. An experimental protocol for the determination of $\mathrm{OH}$ radical rate constants with organics using methyl nitrite photolysis as an $\mathrm{OH}$ radical source. J. Air Pollut. Control Assoc. 31 (10), 1090, 1981.

32. HUANG M.Q., HAO L.Q., GU, X.J., HU, C.J., ZHAO W.X., WANG Z.Y., FANG L., ZHANG, W.J. Effects of inorganic seed aerosols on the growth and chemical composition of secondary organic aerosol formed from $\mathrm{OH}$-initiated oxidation of toluene. J. Atmos. Chem. 70 (2), 151, 2013.

33. GARLAND R.M., WISE M.E., BEAVER M.R., DEWITT H.L., AIKEN A.C., JIMENEZ J.L., TOLBERT M.A. Impact of palmitic acid coating on the water uptake and loss of ammonium sulfate particles. Atmos. Chem. Phys. 5 (7), 1951, 2005.

34. NOZIÈRE B., DZIEDZIC P., CÓRDOVA A. Products and kinetics of the liquid-phase reaction of glyoxal catalyzed by ammonium ions $\left(\mathrm{NH}_{4}^{+}\right)$. J. Phys. Chem. A 113 (1), 231, 2009.

35. YU G., BAYER A.R., GALLOWAY M.M., KORSHAVN K.J., FRY C.G., KEUTSCH F.N. Glyoxal in aqueous ammonium sulfate solutions: products, kinetics and hydration effects. Environ. Sci. Technol. 45 (15), 6336, 2011.

36. KAMPF C.J., JAKOB R., HOFFMANN T. Identification and characterization of aging products in the glyoxal/ ammonium sulfate system - implications for light-absorbing material in atmospheric aerosols. Atmos. Chem. Phys. 12 (14), 6323, 2012.

37. MEYER N.K.; DUPLISSY J., GYSEL M., METZGER A., DOMMEN J., WEINGARTNER E., ALFARRA M.R., FLETCHER C., GOOD N., MCFIGGANS, G., JONSSON A.M., HALLQUIST M., BALTENSPERGER U., RISTOVSKI Z.D. Analysis of the hygroscopic and volatile properties of ammonium sulphate seeded and un-seeded SOA particles. Atmos. Chem. Phys. 9 (2), 721, 2009.

38. GROSS D.S., GÄLLI M.E., KALBERER M., PREVOT A.S.H., DOMMEN J., ALFARRA M.R., DUPLISSY J., GAEGGELER K., GASCHO A., METZGER A., BALTENSPERGER U. Real-time measurement of oligomeric species in secondary organic aerosol with the aerosol time-of-flight mass spectrometer. Anal. Chem. 78 (7), 2130, 2006. 
